\title{
Causes of construction delay from contractors and suppliers in Thailand's oil and gas platform projects
}

\author{
Pittayaporn Gomarn ${ }^{1, *}$, and Jakrapong Pongpeng ${ }^{1}$ \\ ${ }^{1}$ Civil Engineering Department, Faculty of Engineering, King Mongkut's Institute of Technology Ladkrabang, Bangkok, Thailand
}

\begin{abstract}
Construction project delays caused by contractors and suppliers are the top problems in Thailand's oil and gas industries. Recognizing this importance and their relationships between factors can help reduce the risk of delays in construction projects. Therefore, this study set out to confirm factors and inspect relationships between delay factors of contractors and suppliers. A 16 item questionnaire survey was distributed to 134 managers, engineers, and supervisors in oil and gas platform construction projects in Thailand. A confirmatory factor analysis (CFA) was performed by the use of Amos Version 20 software program. The analysis results showed that delays caused by the contractors and suppliers had high relationships, due to high regression weighs. The delays caused by the contractors included seven factors which included poor site management and supervision (17\%), lack of safety rules and regulations (16\%), poor communication and coordination with others (15\%), poor procurement system management $(15 \%)$, defective components and mistakes during construction (14\%), supplier payments lateness (13\%), and poor planning and scheduling (10\%). The delays caused by the suppliers included six factors which included the supply of unqualified and unskilled personnel (22\%), supply of low efficiency equipment (20\%), late delivery of materials and equipment $(20 \%)$, supply of low quality materials $(16 \%)$, late supply of workers $(16 \%)$, and price escalation $(5 \%)$.
\end{abstract}

\section{Introduction}

Over the years, construction project delays cast a dark shadow over many construction projects, with the most important being caused by the stakeholders. Confirmation of this has come from Fallahnejad, which reported that in many countries (including Iran), delays caused by contractors and suppliers are in the top 10 reasons for delay in the oil and gas industry [1].

Ruqaishi and Bashir [2] also indicated that poor site management and contractor supervision (such as ineffective planning and scheduling) are the main causes of the oil and gas construction projects delays in Oman. In Malaysia, the most important causes are reported to also be planning and scheduling, and contractor site management [3].

In Jordan construction projects, evidence shows that contractor financial difficulties are common causes of project delays [4]. Assaf and Al-Hejji [5] conducted a site survey of 23 contractors in Saudi Arabia to determine the causes of delays, and found that $76 \%$ of the most common causes come from contractor difficulties in financing, poor site management, poor communication, poor planning and scheduling, and improper construction methods.

This is supported by Aziz [6], which surveyed postrevolution construction project delays in private, public, and local general construction firms. Results showed that significant contributing factors include ineffective contractor project planning and scheduling $(83.9 \%)$, poor site management and supervision $(83.8 \%)$, poor site financial control $(82.3 \%)$, and reworks due to errors $(82.1 \%)$. Another survey result from Jordan indicated that construction projects delays were often caused by financing and payments [7].

Doloi and others [8] studied 45 key factors affecting project delays in the Indian construction industry. Results indicated that the most critical factors were lack of commitment $(11.6 \%)$, which included a lack of safety measures and the use of improper or obsolete construction methods. Second was inefficient site management $(10.9 \%)$, which included poor site management and supervision. Third, was improper planning (10.8\%), which included lateness in materials procurement), and finally, lack of communication $(8.6 \%)$.

In Thailand, construction delays often mean time and cost overruns. Ogunlana and Promkuntong [9] explored delays of high-rise building projects in Bangkok, and found that most delays could be tracked back to problems caused by contractors and suppliers. The main reasons stated for these delays by contractors were materials management problems $(75 \%)$, coordination deficiencies $(67 \%)$, and planning and scheduling problems $(58 \%)$. Delays by suppliers were related to late delivery $(41 \%)$, price escalation $(16 \%)$, and supply of low quality materials $(8 \%)$.

\footnotetext{
* Corresponding author: gomarnp@gmail.com
} 
Given both the financial importance caused by delays and the fact that project delays can contribute to site safety issues. However, the oil and gas platform construction projects and general construction projects have a different contractual project delivery system. Therefore, researchers wanted to survey and study delay causes and factors in Thailand's oil and gas platform construction projects caused by contractors and suppliers. The results of this study can be applied in the risk assessment analysis, and help with the prevention and reduction of project delays.

\section{Research methods}

\subsection{The conceptual framework}

From a review of the literature, Table 1 is used to present the primary reasons for construction project delays by contractors and suppliers.

Table 1. Cause of project delay from contractor and supplier factors.

\begin{tabular}{|l|c|c|c|c|c|c|c|c|c|}
\hline & $\begin{array}{c}{[1]} \\
*\end{array}$ & $\begin{array}{c}{[2]} \\
*\end{array}$ & $\begin{array}{c}{[3]} \\
*\end{array}$ & $\begin{array}{c}{[4]} \\
*\end{array}$ & $\begin{array}{c}{[5]} \\
*\end{array}$ & $\begin{array}{c}{[6]} \\
*\end{array}$ & $\begin{array}{c}{[7]} \\
*\end{array}$ & $\begin{array}{c}{[8]} \\
*\end{array}$ & $\begin{array}{c}{[9]} \\
*\end{array}$ \\
\hline $\mathrm{C} 1 * *$ & & $\mathrm{x}$ & $\mathrm{x}$ & $\mathrm{x}$ & $\mathrm{x}$ & $\mathrm{x}$ & $\mathrm{x}$ & & $\mathrm{x}$ \\
\hline $\mathrm{C} 3 * *$ & $\mathrm{x}$ & & $\mathrm{x}$ & & $\mathrm{x}$ & $\mathrm{x}$ & $\mathrm{x}$ & $\mathrm{x}$ & $\mathrm{x}$ \\
\hline $\mathrm{C} 4 * *$ & & $\mathrm{x}$ & $\mathrm{x}$ & $\mathrm{x}$ & $\mathrm{x}$ & $\mathrm{x}$ & $\mathrm{x}$ & $\mathrm{x}$ & \\
\hline $\mathrm{C} 5 * *$ & $\mathrm{x}$ & & & $\mathrm{x}$ & & $\mathrm{x}$ & & $\mathrm{x}$ & \\
\hline $\mathrm{C} 6 * *$ & $\mathrm{x}$ & $\mathrm{x}$ & $\mathrm{x}$ & & $\mathrm{x}$ & $\mathrm{x}$ & $\mathrm{x}$ & $\mathrm{x}$ & \\
\hline $\mathrm{C} 7 * *$ & & & & $\mathrm{x}$ & $\mathrm{x}$ & $\mathrm{x}$ & & $\mathrm{x}$ & \\
\hline $\mathrm{S} 1 * *$ & & & & & & & & $\mathrm{x}$ & $\mathrm{x}$ \\
\hline $\mathrm{S} 2 * *$ & & $\mathrm{x}$ & & $\mathrm{x}$ & $\mathrm{x}$ & $\mathrm{x}$ & & $\mathrm{x}$ & $\mathrm{x}$ \\
\hline $\mathrm{S} 3 * *$ & & & $\mathrm{x}$ & & & $\mathrm{x}$ & $\mathrm{x}$ & & $\mathrm{x}$ \\
\hline $\mathrm{S} 4 * *$ & & $\mathrm{x}$ & & $\mathrm{x}$ & $\mathrm{x}$ & $\mathrm{x}$ & & & \\
\hline $\mathrm{S} 5 * *$ & & & $\mathrm{x}$ & & $\mathrm{x}$ & $\mathrm{x}$ & $\mathrm{x}$ & & \\
\hline $\mathrm{S} 6 * *$ & $\mathrm{x}$ & $\mathrm{x}$ & & & $\mathrm{x}$ & $\mathrm{x}$ & & $\mathrm{x}$ & \\
\hline
\end{tabular}

*References and ${ }^{* *}$ contractor $(\mathrm{C})$ and supplier (S) factors

\subsection{Panel of experts}

This research was discussed with three experts to define and finalize factors from the literature review, from which, Table 1 was created as a summary of the related factors. Additionally, the observed factors were finalized into two classification groups related to contractors (C) and suppliers $(\mathrm{S})$.

\subsection{The research instrument}

To analyse the observed factors and inspect the relationships between the latent factors, a 5-level, Likert type agreement survey was used for data collection.

Part 1 of the questionnaire contained items related to the individual's position level, experience and project value. Part 2 of the survey asked the individual to evaluate the importance level of the cause of project delay from contractors and suppliers on a Likert type scale from 1 to 5 , with " 1 " indicating the importance level of the item as very low, whereas a " 5 " rated the importance level of the item as very high [10].

\subsection{Content and construct validity}

\subsubsection{Content validity}

The questionnaire was discussed with three experts (the experts are working as suppliers and contractors in the offshore oil and gas industry with experiences more than fifteen years) to ensure content validity.

\subsubsection{Construct validity}

The Spearman Rank Correlation was used to ensure construct validity of the questionnaire. The correlation coefficient is a measure of the relationship between factors from a -1 to $a+1$ [11]. In this study, the observed factors were determined to be correlated.

Cronbach's alpha was also used to test the internal consistency (reliability) of the questionnaire. The criteria value of Cronbach's alpha is suggested to be above 0.7 [12]. In this study, the Cronbach's alpha value of 0.866 is determined.

\section{Results}

\subsection{Respondent's characteristics}

A total of 134 questionnaires were returned from the respondents having experienced in oil and gas platform construction projects in Gulf of Thailand. Of these $4.5 \%$ were managers, $67.2 \%$ were engineers, and $28.4 \%$ were supervisors (Table 2). Experience level responses indicated that $41.8 \%$ had 5-10 years' experience. Also, $36.6 \%$ worked in enterprises valued at over 1 billion Thai baht (\$31.4 million).

\subsection{Confirmatory factor analysis (CFA)}

A CFA was used to analyze and confirm the sets of observed factors and relationships between the latent factors by using the IBM ${ }^{\circledR}$ SPSS $®$ Amos ${ }^{\text {TM }} 20$ software program. Fit of the CFA model included the indices Chisquares's p-value, relative chi-square $(\chi 2=d f)$, goodnessof-fit index (GFI), and the root mean square error of approximation (RMSEA). [13, 14] The criteria and index values of the goodness-of-fit (GOF) are presented in Table 3. 
Table 2. Demographic characteristic

\begin{tabular}{|l|c|c|}
\hline Position level & Quantity & Percent \\
\hline Manager level & 6 & $4.5 \%$ \\
\hline Engineer level & 90 & $67.2 \%$ \\
\hline Supervisor level & 38 & $28.4 \%$ \\
\hline Experience & Quantity & Percent \\
\hline Less than 5 years & 28 & $20.9 \%$ \\
\hline $5-10$ years & 56 & $41.8 \%$ \\
\hline $11-15$ years & 30 & $22.4 \%$ \\
\hline More than 15 years & 20 & $14.9 \%$ \\
\hline Project value & Quantity & Percent \\
\hline Less than 100 million THB & 27 & $20.1 \%$ \\
\hline $100-500$ million THB & 17 & $12.7 \%$ \\
\hline $501-1000$ million THB & 41 & $30.6 \%$ \\
\hline More than 1 billion THB & 49 & $36.6 \%$ \\
\hline
\end{tabular}

\subsection{Data analysis}

Table 3 shows the results of the goodness-of-fit (GOF) criteria and recommended index values.

Table 3. Goodness-of-fit criteria and indices.

\begin{tabular}{|c|c|c|c|}
\hline \multirow{2}{*}{$\begin{array}{c}\text { GOF recommended } \\
\text { index values }\end{array}$} & Contractor & Supplier & $\begin{array}{c}|c| \\
\text { CFA* } \\
\text { Relationship } \\
\text { between } \\
\text { contractor } \\
\text { and supplier }\end{array}$ \\
\hline $0.05<\mathrm{p} \leq 1.00$ & 0.055 & 0.050 & 0.077 \\
\hline $0 \leq \chi^{2 / \mathrm{df}} \leq 2$ & 1.668 & 1.936 & 1.280 \\
\hline $0.09 \leq \mathrm{GFI} \leq 1.00$ & 0.952 & 0.964 & 0.930 \\
\hline $0 \leq \mathrm{RMSEA} \leq 0.08$ & 0.071 & 0.084 & 0.046 \\
\hline
\end{tabular}

*Remarks: The delay factor of price escalation (S1) was removed from the supplier factors, because S1 does not significantly results delays from the supplier.

Fig.1 shows the CFA analysis results of the factors and their relationships between contractor and supplier delay causes. The results indicated that the delay causes from contractors has a high correlation with delay causes from suppliers, as the regression weight was 0.78 . Information suggests that this is due to the majority of the suppliers and subcontractors have to work under the main contractors due to financial capability and production capacity of the project's requirements. Therefore, any supplier mistakes and delays directly affect contractors. These include items such as the supply of low quality materials, low efficiency of equipment, and unqualified and unskilled personnel to the contractor. Meanwhile, any delays caused from contractors affect suppliers also. These include poor supplier communication and coordination, and contractor late payments to suppliers.

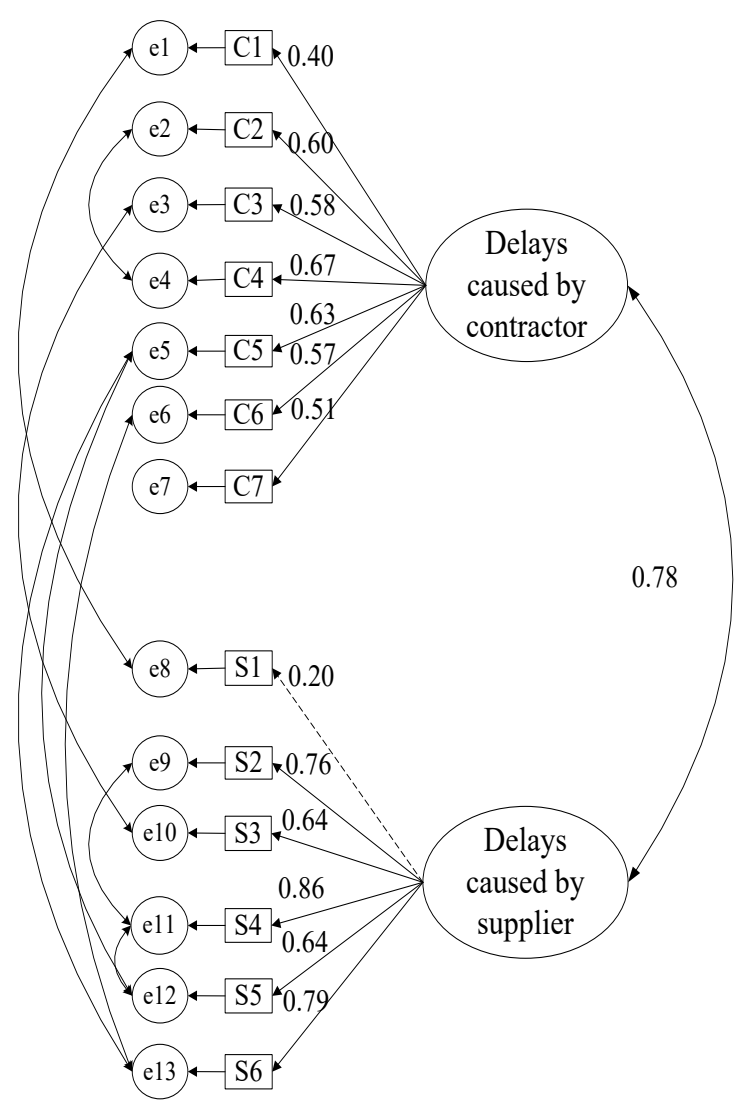

Fig. 1. CFA results.

Table 4 shows the factor loadings for delays caused by construction project contractor, with poor site management and supervision being the leading cause for delay.

Table 5 shows the factor loadings for delays caused by the construction project supplier, with the supply of unqualified and unskilled personnel being the number one reason for delay.

Normally, in construction projects, a key element is management's knowledge and experience. If however key personnel within the organization lack the required project management knowledge, experience, and supervisory skills, projects will have a much higher probability of experience a delay and possibility even a project's failure. Also, if the suppliers assign and supply unqualified and unskilled personnel to the project organization and team, those projects also have a high chance of delay and failure also. 
Table 4. Factor loading of delays causes by the contractor.

\begin{tabular}{|c|c|c|}
\hline Project delay causes & $\begin{array}{c}\text { Regression } \\
\text { weights }\end{array}$ & $\begin{array}{c}\text { Factors } \\
\text { loading }\end{array}$ \\
\hline $\begin{array}{c}\text { C1: Poor planning and } \\
\text { scheduling }\end{array}$ & 0.40 & $10 \%$ \\
\hline $\begin{array}{c}\text { C2: Poor communication and } \\
\text { coordination with others }\end{array}$ & 0.60 & $15 \%$ \\
\hline $\begin{array}{c}\text { C3: Poor procurement system } \\
\text { management }\end{array}$ & 0.58 & $15 \%$ \\
\hline $\begin{array}{c}\text { C4: Poor site management and } \\
\text { supervision }\end{array}$ & 0.67 & $17 \%$ \\
\hline $\begin{array}{c}\text { C5: Lack of safety rules and } \\
\text { regulations }\end{array}$ & 0.63 & $16 \%$ \\
\hline $\begin{array}{l}\text { C6: Defective material and } \\
\text { mistakes during } \\
\text { construction }\end{array}$ & 0.51 & $13 \%$ \\
\hline \begin{tabular}{c} 
C7: Late payments to suppliers \\
\hline
\end{tabular} & $0.51 \%$ \\
\hline
\end{tabular}

Table 5. Factor loading of delays causes by the supplier.

\begin{tabular}{|c|c|c|}
\hline Project delay causes & $\begin{array}{c}\text { Regression } \\
\text { weights }\end{array}$ & $\begin{array}{c}\text { Factors } \\
\text { loading }\end{array}$ \\
\hline S1: Price escalation & 0.20 & $5 \%$ \\
\hline $\begin{array}{c}\text { S2: Late delivery of materials } \\
\text { and equipment }\end{array}$ & 0.76 & $20 \%$ \\
\hline $\begin{array}{c}\text { S3: Supply of low quality } \\
\text { materials }\end{array}$ & 0.64 & $16 \%$ \\
\hline $\begin{array}{c}\text { S4 :Supply of unqualified } \\
\text { and unskilled personnel }\end{array}$ & 0.86 & $22 \%$ \\
\hline S5: Late supply of workers & 0.64 & $16 \%$ \\
\hline $\begin{array}{c}\text { S6: Supply of low efficiency } \\
\text { equipment }\end{array}$ & 0.79 & $20 \%$ \\
\hline
\end{tabular}

Remarks: S1 does not significantly indicate delays from the supplier (p-value $<0.05$ ).

\section{Conclusion}

From the use and analysis of a CFA on contractor and supplier delay factors, it was determined that there is a significant relationship between the sets of factors.

The major reasons for delays from contractors in construction projects are poor site management and supervision, lack of safety rules and regulations, poor communication and coordination with others, poor procurement system management, defective components and mistakes during construction, late payments to suppliers, and poor planning and scheduling, respectively.

The delays caused by suppliers in construction projects are the supply of unqualified and unskilled personnel, supply of low efficiency equipment, late delivery of materials and equipment, supply of materials of low quality, late supply of workers, respectively. In addition, price escalation had a low impact on project delay from supplier's causes.

Finally, this analysis points to the key factors that have been confirmed and the relationship between the delays caused by the contractors and the suppliers. These results may help to reduce and prevent delay risk in ongoing and future oil and gas platform construction projects. Furthermore, the project controller should take a stronger role in evaluating contractors and suppliers in the project's prequalification phase and additionally monitor projects during the execution phase.

The results of this study should be defined with a limitations as the conceptual framework was developed based on the experts experience and an international literature review. Therefore, further inspection of the project types is required.

\section{References}

1. M.H. Fallahnejad, Int. J. Proj. Manag. 31(1), 136146 (2013)

2. M. Ruqaishi, H.A. Bashir, J. Manag. Eng. 31(3), 18 (2015)

3. M. Sambasivan, Y.W. Soon, Int. J. Proj. Manag. 25 (5), 517-526 (2007)

4. G. Sweis, R. Sweis, A. Abu Hammad, A. Shboul, Int. J. Proj. Manag. 26 (6), 665-674 (2008)

5. S.A. Assaf, S. Al-Hejji, Int. J. Proj. Manag. 24 (4), 349-357 (2006)

6. B.R. Aziz, Alexandria Eng. J. 52, 387-406 (2013)

7. A.M. Odeh, H.T. Battaineh, Int. J. Proj. Manag. 20 (1), 67-73 (2002)

8. H. Doloi, A. Sawhney, S. Rentala, Int. J. Proj. Manag. 30 (4), 479-489 (2012)

9. S.O. Ogunlana, K. Promkuntong, V. Jearkjirm, Int. J. Proj. Manag. 14 (1), 37-45 (1996)

10. R. Likert, Social psychology: Experimentation, theory, research (Intext, Scranton, PA, 1972)

11. SPSS Training Department, Survey research using SPSS. (SPSS, Inc., Chicago, 1998)

12. J. Nunnally, Psychometric theory (McGraw-Hill. New York, 1967)

13. J.L. Arbuckle, IBM SPSS amoss 20 user's guide (IBM Corporation. U.S.A., 2011)

14. K. Schermelleh-Engell, H. Moosbrugger, Meths. Psych. Resea. 8 (2), 23-74 (2003) 